\title{
Teaching Finance in the Post-GFC Environment: Quomodo hic habetur, et Quo hinc?*
}

\author{
Richard I. Copp** \\ Griffith University, Australia \\ * How did we get here, and Where to from here? \\ ** The author has benefited from comments by Dr. Joanne Copp, Prof. H. M. Kolsen, Prof. Eugene \\ Clark, Prof. Eduardo Roca, and two anonymous referees. All errors remain the author's \\ responsibility.
}

\begin{abstract}
Despite criticism in the wake of the GFC, history shows that theory and curricula adapt to rectify any disconnects between theory, curricula, and practice. Finance theory unquestionably has antecedents in economics, accounting, legal theory, and psychology. Some theoretical developments - including the moral hazard consequences of limited liability - have yet to filter through to many texts and curricula, which also omit explanations of uncertainty; incomplete and (sub)optimal contracting; contagion; and behavioural finance. Student learning outcomes could be enhanced if universities, perhaps in a final year, cross-disciplinary "capstone" course, empowered students to understand the financial documentation evidencing sophisticated transactions; map relevant cash flows and wealth transfers; and recognise Ponzi schemes, the ethics of stakeholder wealth transfers, the conditions for contagion, and incentives for adverse selection and moral hazard in practice.
\end{abstract}

Keywords: Global Financial Crisis (GFC), efficient market, rational expectations, ethics, incomplete contracts, optimal contracting, contagion, moral hazard, uncertainty, behavioural finance, anchoring, belief perseverance, cross-disciplinary, wealth transfer, student learning, capstone.

\section{Introduction}

Finance curricula in Universities have been criticized in the financial press in the wake of the Global Financial Crisis (GFC) for over-emphasizing the efficient market theory ${ }^{1}$ and rational expectations ${ }^{2}$ at the expense of ignoring the ethics of human behaviour. ${ }^{3}$

1. A capital market is said to be efficient if security prices fully and instantaneously reflect all available relevant information: see Copeland, T. E., Weston, J. F., and Shastri, K. (2005), Financial Theory and Corporate Policy, $4^{\text {th }}$ ed., New York: Pearson Addison Wesley, p. 354.

2. Investor expectations are defined as rational if "prices are formed on the basis of expected future payouts of the assets, including their resale value to third parties. Thus a rational expectations market is an efficient market because prices will reflect all information": Copeland et al., op. cit., p. 360. 
This article identifies key aspects of finance theory that relate to many of the complex financial securitization transactions, which before the GFC were underemphasized in most tertiary finance studies. ${ }^{4}$ It suggests that the usefulness of finance curricula - and students' learning outcomes - in future could be considerably enhanced by their prominent inclusion in core and "capstone" courses. $^{5}$ Using a cross-disciplinary approach, finance students could be empowered to:

i. Read the publicly available disclosure documents evidencing sophisticated financial products and transactions in practice, with a view to:

- mapping the cash flows and wealth transfers between stakeholders;

- if appropriate, re-arranging the cash flows to derive new financial products and verify whether these would breach the law; and

ii. Recognise:

- the moral hazard effects of limited liability conferred by corporations legislation, ${ }^{6}$ and all the checks and balances which become necessary as a consequence;

- Ponzi $^{7}$ and other wealth transfer schemes in practice;

3. The Turner Review (2009), A Regulatory Response to the Global Banking Crisis, Financial Services Authority, London UK, March, pp. 40-41; and Ball, R. (2009), "The Global Financial Crisis and the Efficient Market Hypothesis: What Have We Learned?", Journal of Applied Corporate Finance, 21(4): pp. 8-16.

4. It is only the last two generations which have fully realised the many benefits of the arrangements for exploitation offered by the present system of legal regulation. On a related front, perhaps a more fundamental review is required than looking at each breach. Such analysis, however, is best left for another paper.

5. Universities have historically "compartmentalised" knowledge into specialist areas, and students normally gain knowledge in several discrete areas. A "capstone" subject or course generally gives final semester students an opportunity to apply the knowledge they have gained throughout their degree to solve "client" problems in a more "real world" context. It allows students to see the interconnections between previously disparate areas of knowledge, apply the knowledge they have learned, and be better prepared for the workplace. See for example, Jervis, K. J. and Hartley, C. A. (2005), "Learning to Design and Teach an Accounting Capstone", Issues in Accounting Education, 20(4): pp. 311-339. The "capstone" is the capping or finishing stone at the top of a masonry wall or building structure in architecture.

6. Cf. Marshall, A. (1890), Principles of Economics, $8^{\text {th }}$ ed., London: Macmillan, p. 303 (1982 reprint); and Borosage, R. (2002), "The Nation", February, cited at Beder, S. (2003), Power Play, Melbourne: Scribe Publications, p. 176.

7. The issue of the identification of Ponzi schemes is developing in the literature in the wake of the Madoff scandal. See for instance, Drew, J. and Drew, M. (2010), "The Identification of Ponzi Schemes: Can a Picture Tell a Thousand Frauds?", Griffith Law Review, 19(1): pp. 5170; and Gregoriou, G. and Lhabitant, F. (2009), "Madoff: A Flock of Red Flags", Journal of Wealth Management, 12(1): pp. 89-97. 
- the ethical implications of transferring wealth from security holders to management or the Board, or between classes of security holders;

- the conditions under which contagion between stakeholder groups could occur; and

- the incentives for adverse selection and moral hazard in particular schemes in practice.

By doing so, not only would students' learning outcomes be enhanced, but we could be better assured that future students might later contribute to articulating a finance theory that encompasses these realities. The emphasis of the article is therefore primarily pedagogical. It addresses finance theory only insofar as this is necessary to enhance teaching and learning outcomes. The recommended changes relate not so much to what content is taught, but how to teach it and what is emphasized.

In order to further identify these key aspects of theory, however, we must first examine how we got to this point.

\section{How Did We Get Here? Quomodo hic habetur?}

The GFC was characterized chiefly by the following:

- It was claimed to be a unique event, ${ }^{8}$ which which suggests uncertainty as distinct from risk simpliciter;

- Some firms, apparently "too big to fail", were bailed out by government, ${ }^{9}$ suggesting moral hazard;

- As a result of their remuneration packages, management's incentives were often to undertake highly risky investments ${ }^{10}$ of which major shareholders, were they aware, would not approve. This is suggestive of incomplete and/or sub-optimal contracting; and the selection of

8. Cf. The Turner Review, op. cit., p. 40.

9. UK Independent Commission on Banking (2011), Interim Report: Consultation on Reform Options, April, London, p. 6; House of Commons Treasury Committee (2011), Competition and Choice in Retail Banking, Vol. 1, London, p. 3, 23; Senate Economic References Committee (2011), Competition within the Australian Banking Sector, Commonwealth of Australia, Canberra, May, pp. 205-206. Cf. Watts, R. L. and Zimmerman, J. L. (1978), "Towards a Positive Theory of the Determination of Accounting Standards", The Accounting Review, January, pp. 112-134.

10. Parliamentary Joint Committee on Corporations and Financial Services, Report of the Parliamentary Enquiry into Financial Products and Services in Australia, Commonwealth of Australia, Canberra, November 2009. 
management with such a risk profile at least raises suspicions of an adverse selection problem;

- Losses spread between institutions and even countries, apparently evidencing a contagion effect;

- Legal arrangements and documentation for securitizations and other financing schemes which were so complex that even "sophisticated investors" (as legally defined) failed to understand the risks and uncertainties involved, ${ }^{11}$ suggesting information asymmetry or ignorance, and possibly even incomplete or sub-optimal contracting issues;

- Overconfidence, and a persistent (published) belief or opinion that everything would be all right, ${ }^{12}$ which raises behavioural finance issues such as belief perseverance; and

- Arguably, a lack of ethics. ${ }^{13}$

It is true that these features of the GFC would be recognized in many extant curricula not as finance, but as economics; law and accounting theory; psychology; and/or philosophy. However, the problem for extant curricula, which depend for their development on journals and textbooks, ${ }^{14}$ is that while leading finance journals are now (and have some time been) addressing these developments in practice, most finance textbooks and curricula are not-and while it may take around a further eight years for curricula to catch up, ${ }^{15}$ finance students would greatly benefit from an understanding of these issues now.

In an effort to understand how we got to this point, the following section traces the intellectual lineage of finance theory as presented in current textbooks

11. O'Brien, J. (2009), Engineering a Financial Bloodbath, London: Imperial College Press.

12. See Shiller, R. J. (2005), Irrational Exuberance, Princeton N.J.: Princeton University Press.

13. See for example, Grayling, A. C. (2010), Thinking of Answers, London: Bloomsbury, pp. 8283; Buchanan, J. M. "Markets, States and the Extent of Morals", American Economic Review, 68(2): pp. 364-368, at 365; and Patinkin, D. (1973), "Frank Knight as Teacher", American Economic Review, 63(5): pp. 787-810 at 801-802.

14. In finance, as in many disciplines, the chief source of new ideas is scholarly journal articles, whose content and essential reasoning are later published in textbooks, which form the basis for teaching curricula. Often (though not always), changes in curricula then encroach on and influence finance practice, in a manner reminiscent of Keynes' "practical men" who are beholden for their ideas to "some academic scribbler of a few years back": cf. Keynes, J. M. (1936), The General Theory of Employment, Interest and Money, London: Macmillan, p. 383.

15. Frequently textbooks lag journals by $3-5$ years, and then general business practice probably lags good textbooks by another 2-3 years: cf. Weston, J. F. (1970), "The State of the Finance Field", Journal of Finance, 25(1): pp. 1-17, at 16. This is not, however, always the case. Sometimes, the journals lag developments in practice - as with finance journals in the wake of the GFC. 
and - by extension - curricula, ${ }^{16}$ along the lines of what has long been labeled "history of economic thought" by economists. ${ }^{17}$

\subsection{Intellectual Lineage of Finance Theory}

There is apparently a misconception that finance theory, like Aphrodite, emerged fully formed ${ }^{18}$ with the publication of Harry Markowitz' 1952 article on portfolio management, ${ }^{19}$ or at the latest in 1969 with the publication by Gene Fama, Lawrence Fisher, Michael Jensen, and Richard Roll of their event study on stock price reactions to news. ${ }^{20}$ Certainly it is true that modern empirics emerged around this time, but that was largely due to technological advances in data processing. Before this time, some argue, earlier economists were so well versed in practical institutions, history and data that they did not need to be so "empirical" in today's sense of that term. ${ }^{21}$

Finance theory has its roots in ancient Greece around c. 624 B.C. - c. 546 B.C., when Aristotle observed speculation in olive oil futures options. ${ }^{22}$ Traders in the Roman Empire were familiar with bubbles and busts, public issues of debt and equity securities, investment and lending with interest, bills of exchange, trade finance, and even the formation of some joint stock companies. ${ }^{23}$ The Arabs preserved much of the ancient Greek and Egyptian literature during the mediaeval period. Trade finance and taxation flourished during the Renaissance. ${ }^{24}$ Adam

16. See "Historical Development of Finance Curricula" below.

17. Cf. Cambridge University Press, Journal of the History of Economic Thought; and Schumpeter, J. A. (1954), History of Economic Analysis, New York: Oxford University Press.

18. Cf. Plinius, Secudus, C. (Pliny the Elder)(77-79 AD), Naturalis Historia: the Elder Pliny's Chapters on the history of Art, trans. by K. Jex-Blake, Chicago: Ares, 1976 (originally published in 77-79AD).

19. Markowitz, H. (1952), "Portfolio Selection", Journal of Finance, 7(1): pp. 77-91. Even Markowitz himself acknowledged that he was often called the "father of modern portfolio theory", although he characteristically sought to share this honour with A. D. Roy: see Markowitz, H. (1999), "The Early History of Portfolio Theory: 1600-1960", Financial Analysts Journal, 55(4): pp. 5-16, at 5-6.

20. While Australians Ray Ball and Philip Brown published their paper in 1968, the first event study actually undertaken was by Fama, Fisher, Jensen, and Roll, published in 1969 as Fama, E., Fisher, L., Jensen, M., and Roll, R. (1969), "The Adjustment of Stock Prices to New Information", International Economic Review, 10: pp. 1-21. Ball and Brown's paper was of course published as Ball, R. and Brown, P. (1968), "An Empirical Evaluation of Accounting Income Numbers", Journal of Accounting Research, 6: pp. 159-178. Cf. Copeland, Weston, and Shastri (2005), op. cit., p. 866, who consider that modern corporate finance theory started with Modigliani and Miller's 1958 and 1963 papers on capital structure and firm value. Markowitz' 1952 paper of course predated these articles by some six years.

21. See for instance Harcourt, G. (1979), "Joan Robinson: Portrait of a Lady”, Working Paper 791, University of Adelaide, p. 20 - later published as Harcourt, G. C., Biographical Supplement to the International Encyclopaedia of the Social Sciences, 1979. See also Harcourt, G. C. (1995), “Obituary: Joan Robinson 1903-1983”, Economic Journal, 105(432): pp. 1228-1243.

22. Aristotle, The Politics, Vol. 2, Book 1, trans. by John Gillies, London, 1813, pp. 53-54 (originally published circa $355 \mathrm{BC}$ ). 
Smith records that the industrial revolution saw the rise of joint stock companies. ${ }^{25}$ The late 1700 s to early 1800 s also saw the rise of public markets for investment securities ${ }^{26}$ issued for new infrastructure projects. ${ }^{27}$

Modern finance theory has its antecedents primarily in economics and accounting theory. Economics was itself influenced early by psychology and biology, ${ }^{28}$ while modern accounting theory owes much to economics, ${ }^{29}$ legal theory ${ }^{30}$ and psychology. ${ }^{31}$ This section focuses on those financial economists whose original contributions were crucial to the development of finance thought. The next section concentrates on the historical evolution of texts and curricula. The aim is to provide a panoramic view ${ }^{32}$ of the subject - to paraphrase Newton, if we can see "farther, it is only by standing on the shoulders of giants." 33

Economists and lawyers both claim, from the United Kingdom, Jeremy Bentham (1789) and his godson John Stuart Mill (1863) as pivotal in the development of utility theory and the legal jurisprudence that underpins optimal contracting theory. Alfred Marshall (1890) and F. Y. Edgeworth (1881) were also instrumental, ${ }^{34}$ as was Ronald Coase (1937) for putting the concepts in a form suitable for an economic analysis of law and accounting theory. ${ }^{35}$

In the United States, Irving Fisher, renowned in finance for the Fisher Separation theorem and the Fisher equation, received his Ph.D. in mathematical economics from Yale in $1891 .{ }^{36}$ Others who made valuable contributions around this time were Marshall, Pigou, ${ }^{37}$ and Keynes. ${ }^{38}$ Another American, Frank Knight, prominent in finance for his Risk, Uncertainty and Profit (1921), ${ }^{39}$ highlighted the importance of uncertainty in economic and financial analysis, including the fact that while risk can be measured objectively, uncertainty cannot. He taught, among others, Friedman and Stigler at the University of Chicago. ${ }^{40}$

23. Temin, P. (2004), "Financial Intermediation in the Early Roman Empire", The Journal of Economic History, 64(3): pp. 705-733, esp. 719-728.

24. See generally Diamond, A. M. and Diamond, J. M. (1999), "A History of Corporate Finance", Research on the History of Economic Thought and Methodology, 17: pp. 263-270, at 264; Baskin, J. B. and Miranti, P. J. (1997), A History of Corporate Finance, Cambridge, UK: Cambridge University Press; and Gras, N. S. B. (1946), "War and Business: Four CenturyLong Struggles", Bulletin of the Business Historical Society, 20(6): pp. 165-189.

25. Smith, A. (1776), An Inquiry into the Nature and Causes of the Wealth of Nations, Chicago, Ill.: University of Chicago Press, 1976 (originally published in 1776); Smith, A. (1759), The Theory of Moral Sentiments, New York: Penguin, 2009 (originally published in 1759); Marshall, A. (1890), Principles of Economics, $8^{\text {th }}$ ed., London: Macmillan (1982 reprint); Marshall, A. (1923), Money, Credit and Commerce, London: Macmillan; and Marshall, A. (1927), Industry and Trade, $2^{\text {nd }}$ ed., London: Macmillan; and Gower, L. C. B. (1969), The Principles of Modern Company Law, London: Stevens \& Sons, Ch. 2.

26. Diamond, A. M. and Diamond J. M. (1999), loc. cit.; and Baskin, J. B. and Miranti, op. cit.

27. Ibid; and see Marshall (1890, 1923), op. cit.

28. See for instance Arena, R. and Quere, M. (eds.)(2002), The Economics of Alfred Marshall: Revisiting Marshall's Legacy, London: Palgrave Macmillan, at pp. 47, 79, 211, 229, and 267.

29. See for example, Ball, R. and Brown, P. (1968), "An Empirical Evaluation of Accounting Income Numbers”, Journal of Accounting Research, 6: pp. 159-178; and Foster G, Financial Statement Analysis, Prentice-Hall, 1986. All three authors were, incidentally, Australians who received their Ph.D.s in the United States. 
After the Depression, stocks became regarded by investors as largely speculative, in the nature of gambling. ${ }^{41}$ Ben Graham's Security Analysis (1934) was instrumental in resurrecting the respectability of stocks as investments, using techniques of fundamental analysis or "value investing" which are still extolled by his former student Warren Buffett today. ${ }^{42}$

Fred Weston was pivotal, not only for highlighting the possibility of synergies in mergers and acquisitions, but also for publishing an astounding 31 books, 147 journal articles, and chairing 32 doctoral dissertations. Weston supervised Bill Sharpe, ${ }^{43}$ and had a strong influence on Harry Markowitz, famous for his portfolio theory. ${ }^{44}$

In the 1960s and 70s, Sharpe, Treynor and Lintner developed the Capital Asset Pricing Model (CAPM), ${ }^{45}$ and Fama, Fisher, Jensen and Roll (1969) ${ }^{46}$ spawned a massive literature on market efficiency and anomalies to efficient markets and the CAPM. ${ }^{47}$

Fischer Black made seminal contributions to our understanding of risk and return in markets. ${ }^{48} \mathrm{He}$ and Myron Scholes revolutionised the way in which finance theorists thought about asset valuation and other practical problems in finance, developing the Option Pricing Model (OPM) and spawning an enormous literature over 40 years on contingent claims. Miller and Modigliani made contributions to financial capital structure ${ }^{49}$ and, together with Lintner, to dividend theory. ${ }^{50}$

Towering among contemporary finance theorists in the United Kingdom stands Michael Brennan, although he did most of his foundational work in the United States. He is currently a Professor Emeritus at both UCLA Anderson and London Business School.

30. See, for instance, Jensen, M. and Meckling, W. (1976), "Theory of the Firm: Managerial Behaviour, Agency Costs and Ownership Structure", Journal of Financial Economics, 3: pp. 305-360; Jensen, M. (2000), A Theory of the Firm, Cambridge, Mass: Harvard University Press; Alchian, A. and Demsetz, H. (1972), "Production, Information Costs, and Economic Organisation”, American Economic Review, 62: pp. 777-795; Baker, G., Gibbons, R., and Murphy, K. (1999), "Information Authority in Organisations", Journal of Law, Economics, and Organisation, 15: pp. 56-73; Zingales, L. (2000), "In Search of New Foundations", Journal of Finance, 55: pp. 1623-1653; and Berle, A. and Means, G. (1932), The Modern Corporation and Private Property, New York: Macmillan.

31. For evidence of the links between accounting theory and psychology, see any of the seminal articles published in the scholarly journal Accounting, Organizations and Society. Indeed, that journal is sub-titled An International Journal Devoted to the Behavioural, Organizational \& Social Aspects of Accounting; and, according to its Aims and Scope, is premised on "the relationship between accounting and human behaviour, organizational structures and processes, and the changing social and political environment of the enterprise."

32. By its nature, the discussion omits more important contributors than it includes. For example, Paul Samuelson would have included Bachelier, Cowles, Roberts, Domar, Friend, Gollier, and Merton: see Samuelson, P. (2000), "Honouring Founding Fathers of Modern Finance Economics”, Financial Management, 29(3): pp. 92-93.

33. Sir Isaac Newton in a letter to Robert Hooke, 15 February 1676. See eg. Weintraub, D. A. (2011), How Old Is the Universe?, Princeton N.J.: Princeton University Press, p. 217. 
In Australia, theoretical and empirical finance was since the early 1970s dominated by Ball, Brown, Finn and Officer, three of whom received their Ph.D.s from the University of Chicago, and all of whom were largely responsible for educating Australian scholars in efficient markets ${ }^{51}$ and the latest intellectual advances from the North American schools. Tom Valentine ${ }^{52}$ and Ron Bird ${ }^{53}$ also made significant contributions, chiefly through their textbooks, which have been used to educate four decades of students.

Internationally in recent decades, links between psychology and finance have re-emerged as 'behavioural' finance. Scholars such as de Bondt, ${ }^{54}$ Thaler, ${ }^{55}$ Shiller, ${ }^{56}$ Kahneman and Tversky ${ }^{57}$ are the intellectual beneficiaries of psychologists such as Carl Jung and economist Herbert Simon. ${ }^{58}$

Finance theory unquestionably therefore has its antecedents in economics, accounting theory, legal theory, and psychology. In terms of curriculum reform in the wake of the GFC, one relevant issue is the extent to which these crossdisciplinary roots ought be explicitly recognized and utilized.

\subsection{Historical Development of Finance Curricula}

The archiving of university finance curricula is notoriously haphazard. On the assumption that the content of finance curricula from the late $19^{\text {th }}$ century to the present reflects the leading finance textbooks of the time, this section reviews the way in which curricula developed in response to theoretical developments and

34. Koutsoyiannis, A. (1983), Modern Microeconomics, $2^{\text {nd }}$ ed., New York: Macmillan; Marshall, A. (1923), Money, Credit and Commerce, London: Macmillan; Marshall, A. (1927), Industry and Trade, London: Macmillan; Marshall, A, (1982), Principles of Economics, $8^{\text {th }}$ ed., London: Macmillan (originally published in 1890); Edgeworth, F. Y. (1996), Writings in Probability, Statistics and Economics, Cheltenham, UK: Edgar Elgar; Newman, P. (ed.), (1996), F. Y. Edgeworth's Mathematical Psychics and Further Papers on Political Economy, Oxford: Oxford University Press.

35. Coase, R. H. (1937), “The Nature of the Firm”, Economica, 4: pp. 386-405; and Coase, R. H. (1960), "The Problem of Social Cost", Journal of Law and Economics, 3: pp. 1-44.

36. Many of the radical advances in modern finance theory are based in doctoral dissertations from a comparatively small number of universities: cf. for example, Schweser, C. (1977), "The Doctoral Origins of Contributors to the Journal of Finance from 1964 through 1975", Journal of Finance, 32(3): pp. 908-910.

37. Pigou, A. C. (1924), Economics of Welfare, $2^{\text {nd }}$ ed., London: Macmillan.

38. Keynes himself made valuable contributions to finance theory: see for example, Keynes, J. M. (1930), A Treatise on Money, London: Macmillan, II; Keynes, J. M. (1923), Tract on Monetary Reform, London: Macmillan; and Keynes, J. M. (1921), A Treatise on Probability, London: Macmillan.

39. Knight, F. H. (1921), Risk, Uncertainty and Profit, Chicago: University of Chicago Press.

40. See Knight, F. (1926), "Economics at Its Best", American Economic Review, 16(1): pp. 51-58, which is an example of Knight commenting (favourably) on Pigou's (1924) Economics of Welfare, op. cit.; Patinkin, D. (1973), "Frank Knight as Teacher", American Economic Review, 63(5): pp. 787-810; and Emmett, R. B. (2009), Frank Knight and the Chicago School in American Economics, New York:. Routledge.

41. Cf. Keynes, J. M. (1936), op. cit., p. 159. 
market needs. Unsurprisingly, theory, texts and curricula have historically responded to and developed after periods of change - often, turmoil — in the financial markets. ${ }^{59}$

Textbook writers from 1862 to the 1920s engaged in largely descriptive works, seeking to synthesize and organize the lessons of practical industry experience. ${ }^{60}$ The first textbooks - in the modern sense of that term - for finance students were Green's Corporate Finance (1897); ${ }^{61}$ and Carroll's Principles and Practice of Finance (1895). ${ }^{62}$ These books concentrated on external corporate financing, including stocks and bonds, corporate accounting, railroad reports, corporate reorganization and public policy issues.

The Roaring 1920s was dominated by five texts: ${ }^{63}$ Smith on common stocks; ${ }^{64}$ Dewing on corporate financial policy; ${ }^{65}$ Gerstenberg on financial organization; ${ }^{66}$ Chamberlain on bond investment; ${ }^{67}$ and as a direct response to the needs of the time, Bogen on railroad securities. ${ }^{68}$ All of these texts continued the work of synthesizing and organizing finance knowledge begun by the early writers of the late $19^{\text {th }}$ century. These books, and the finance curricula on which they were based, were heavily institutional and intensely detailed, spawning (in finance practice) much meticulous statistical work the purpose of which was to identify particular stocks as profitable investments. ${ }^{69}$

Much of this exhaustive statistical work became discredited in 1929 following the Wall Street collapse, which heralded an enveloping disenchantment

42. See Ellis, C. D. (1982), "Ben Graham: Ideas as Mementos", Financial Analysts Journal, 38(4): pp. 41-42 and 44-48; and Bishop, G. W. (1961),"Evolution of the Dow Theory", Financial Analysts Journal, 17(5), pp. 23-26, at 24.

43. Cf. Markowitz, H. (1999), "The Early History of Portfolio Theory: 1600-1960", Financial Analysts Journal, 55(4): pp. 5-16, at 14.

44. Markowitz, H. (1952), "Portfolio Selection", Journal of Finance, 7 (1): pp. 77-91.

45. See Sharpe, W. F. (1963), "A Simplified Model for Portfolio Analysis", Management Science, pp. 277-293; Sharpe, W. F. (1964), "Capital Asset Prices: A Theory of Market Equilibrium under Conditions of Risk", Journal of Finance, pp. 425-442; Treynor, J. (1961), "Towards a Theory of the Market Value of Risky Assets", unpublished manuscript, cited in Copeland, T. E., Weston, J. F., and Shastri, K. Financial Theory and Corporate Policy, $4^{\text {th }}$ ed., New York: Pearson Addison-Wesley, p. 197; Lintner, J. (1965), "The Valuation of Risk Assets and a Selection of Risky Investments in Stock Portfolios and Capital Budgets", Review of Economics and Statistics, pp. 13-37; Lintner, J. (1969), "The Aggregation of Investors' Diverse Judgements and Preferences in Purely Competitive Security Markets", Journal of Financial and Qualitative Analysis, pp. 347-400. See also Black (1972), "Capital Market Equilibrium with Restricted Borrowing”, Journal of Business, pp. 444-455.

46. Fama, E., Fisher, L., Jensen, M., and Roll, R. (1969), "The Adjustment of Stock Prices to New Information", International Economic Review, 10: pp. 1-21.

47. For a review of much of this literature, see Copeland, T. E., Weston, J. F., and Shastri, K. Financial Theory and Corporate Policy, $4^{\text {th }}$ ed., New York: Pearson Addison-Wesley, Ch. 1011. Some could argue that Stephen Ross, the key innovative mind behind the Arbitrage Pricing Model, should also be included in this list of luminaries. Other useful papers on problems with the capital asset pricing model and anomalies respectively include Haugen, R. (1996), "Finance from a New Perspective", Financial Management, 25(1): pp. 86-97; and Kleidon, A. W. (1986), "Anomalies in Financial Economics: Blueprint for Change?", Journal of Business, Part 2: "The Behavioural Foundations of Economic Theory", 59(4): S469-S499. 
with common stocks as long-term investments. Abandonment of the gold standard by Britain stimulated some, albeit very limited interest in gold stocks as hedges against inflation but, before 1934, there was a widely held view that common stocks were mere speculations, though bonds were "investments" ${ }^{70}$ The conventional wisdom was that financing could be learned "on the job". Stock analysts who lacked inside information ${ }^{71}$ attempted to forecast business conditions and business cycles. ${ }^{72}$

Graham and Dodd's (1934) Security Analysis ${ }^{73}$ made an immense contribution by re-emphasizing that it was possible to make sound investments in common stocks. Graham and Dodd distinguished between what would now be termed "market risk" and "specific risk", and used accounting data and other techniques to identify stocks" "earning power". They believed at the time that diversification among primary stocks would not offer very fruitful opportunities for analysis. ${ }^{74}$

The organizing and synthesizing phase in the development of finance curricula lasted until the post-World War II reconstruction era, when changes in core finance curricula were brought about by four key influences.

The first was a growing recognition, in both the U.S. ${ }^{75}$ and Britain, ${ }^{76}$ of a mismatch between the content of finance curricula and the requirements of finance practice. The textbooks of the period were very heavily institutional in detail, and contrast greatly with later texts of the 1980s and 90s-demonstrating how much finance theory has been revolutionized since 1947.

48. See for instance, Merton, R. and Scholes, M. (1995), "Fischer Black", Journal of Finance, 50(5): pp. 1359-1370, at 1359.

49. Stulz, R. M. (2000), "Merton Miller and Modern Finance", Financial Management, 29(4): pp. 119-131; Modigliani, F. and Miller, M. H. (1958), "The Cost of Capital, Corporation Finance, and the Theory of Investment", American Economic Review, pp. 261-297; Modigliani, F. and Miller, M. H. (1963), "Corporate Taxes and the Cost of Capital: A Correction", American Economic Review, pp. 433-443; and Miller, M. H. (1977), "Debt and Taxes", Journal of Finance, pp. 261-275.

50. Miller, M. H. and Modigliani, F. (1961), "Dividend Policy, Growth and the Valuation of Shares", Journal of Business, pp. 411-433; Modigliani, F. and Miller, M. H., op. cit, 1963; Linter, J. (1956), "Distribution of Incomes of Corporations among Dividends, Retained Earnings and Taxes", American Economic Review, pp. 97-113; Lintner, J. (1964), “Optimal Dividends and Corporate Growth under Uncertainty", Quarterly Journal of Economics, pp. 4995; and Miller, M. H. (1982), "Dividends and Taxes: Some Empirical Evidence”, Journal of Political Economy, pp. 1118-1141.

51. See, for example, many of their papers collected in Ball, R., Brown, P., Finn. F., and Officer, R. (1989), Share Markets and Portfolio Theory: Readings and Australian Evidence, $2^{\text {nd }}$ ed., St Lucia, University of Queensland Press.

52. See for instance, Valentine, T., Ford, G., and Copp, R. (2006), Financial Markets and Institutions in Australia, $2^{\text {nd }}$ ed., Sydney: Pearson Education; Valentine, T. (2007), Modern Financial and Investment Planning, Sydney: Pearson Education.

53. Peirson, G. and Bird, R. (1972), Business Finance, Sydney: McGraw-Hill. This was the first Australian textbook on so-called modern finance theory in Australia: cf. $\mathrm{http}$ //datasearch.uts.edu.au/business/staff/finance/details.cfm?StaffId=77 (accessed 15.8.11). Numerous editions of the book followed: see e.g. Peirson, G., Bird, R., Brown, R. and Howard, P. (1995), Business Finance, $6^{\text {th }}$ ed., McGraw Hill, Sydney. 
The second key factor was that, after the War, corporates were forced to rely significantly on internal funds to finance their operations. ${ }^{77}$ Two conferences reported in the Journal of Finance in 1949 and 1950 about a need to focus on issues concerning working capital and internal financial operations, ${ }^{78}$ and gradually over the decade these topics became embedded in core finance curricula and texts. ${ }^{79}$

Thirdly, there was a growing recognition that finance curricula had become "too [institutionally]complex, too encyclopedic, too demanding of memory at the expense of intellect". 80

Fourth, analytical techniques developed during the War such as mathematical modeling, statistical testing, and operations research began to be used in finance, enabling scholars to empirically test hypotheses within a more theoretical framework. There was gradual recognition that the pre-War literature which had so well synthesized and organized the lessons of practice was useful for suggesting hypotheses, but inadequate for testing them in any systematic way. ${ }^{81}$

During the $1950 \mathrm{~s}$, interest in consumer finance increased, ${ }^{82}$ but it was in the 1960s and 70s that the most innovative theoretical advances in finance thought came to fruition. ${ }^{83}$

In 1970, observed Brennan, one of the (then) "new generation" of theoreticians, the primary consideration of finance theory (and, it could be added, curricula) was how the value of a given cash flow stream might be changed by

54. See for instance De Bondt, W. F. M. and Thaler, R. H. (1985), "Does the Stock Market Overreact?", Journal of Finance, 40(3): pp. 793-805; and De Bondt, W. F. M. and Thaler, R. H. (1987), "Further Evidence on Investor Overreaction and Stock Market Seasonality", Journal of Finance, 42(3): pp. 557-581.

55. See Thaler, R. H. (1964), The Winner's Curse: Paradoxes and Anomalies of Economic Life, Princeton N.J.: Princeton University Press; Thaler, R. H. (1993), Advances in Behavioral Financ, New York: Russell Sage Foundation; and Thaler, R. H. (2005), Advances in Behavioral Finance, Volume II (Roundtable Series in Behavioral Economics), Princeton N.J: Princeton University Press.

56. See eg. Shiller, R. J. (2000), Irrational Exuberance, Princeton N.J., Princeton University Press.

57. See for instance, Kahneman, D. and Tversky, A. (1979), "Prospect Theory: An Analysis of Decision under Risk", Econometrica, 47: pp. 263-291; and Tversky, A. and Kahneman, D. (1991), "Loss Aversion in Riskless Choice: A Reference Dependent Model", Quarterly Journal of Economics, 106: pp. 1039-1061.

58. Simon, H. (1955), "A Behavioral Model of Rational Choice", Quarterly Journal of Economics, 69: pp. 99-188.

59. Cf. Dubin, R. (1978), Theory Building, $2^{\text {nd }}$ ed., New York: Free Press; and Kuhn, T. (1979), The Structure of Scientific Revolutions, Chicago Ill.: University of Chicago Press.

60. See for example, Norgaard, R. L. (1981), "The Evolution of Business Finance Textbooks", Financial Management, 10(2): pp. 34-45; and Ruml, F. (1928), "The Formative Period of Higher Commercial Education in American Universities", The Journal of Business of the University of Chicago, 1(2): pp. 238-263, at 239; and McCrea, R. C. (1926), "Economics in the Business Curriculum", Journal of Political Economy, 34: p. 219. Interestingly, the masterapprentice model dominated the area of money market and foreign-exchange dealing until as late as the early 1980s. It was only after about 1986 - at least in Australia - that University academic curricula focused on these areas as a priority. 
distributing it among different classes of security holders. ${ }^{84}$ By the mid-1990s, however, concern had shifted-largely as a result of insights from agency theory and real option pricing theory that arise under conditions of information asymmetry - to how the structure of claims on the firm affected the cash flow stream itself. ${ }^{85}$ This shift is apparent from a perusal of many of the best-known textbooks over this period. ${ }^{86}$

The move to a more "theoretical" finance theory was largely a reaction to the institutional "fussiness" (to use Brennan's phrase) of previous eras, exemplified by Dewing's Corporate Finance and later editions of Graham, Dodd and Cottle's Security Analysis. In this sense, the new theoretical finance "was in itself a "back to basics' movement, ... relegating institutional details to footnotes." ${ }^{87}$ Whether the "return to basics" movement has given way to an overly mathematical and empirical approach to finance remained somewhat of a vexed question. While there is some merit in the suggestion, it must be remembered that economics, psychology and even (some) legal analysis has also become highly mathematical and empirical in nature. We are abstracting from an ever more complex world.

Despite substantial disruptions to financial markets, ${ }^{88}$ history shows that theory and curricula both adapt to rectify disconnects between them and practice. $^{89}$ The challenge for contemporary finance theorists ${ }^{90}$ and educationalists is to identify any disconnects between theory, curricula and

61. Greene, T. L. (1897), Corporate Finance, GP Putnam's Sons, New York.

62. Carroll, E. (1895), Principles and Practice of Finance: A Practical Guide for Bankers, Merchants and Lawyers, GP Putnam's Sons: New York. Mead, E. S. (1910), Corporation Finance, D. Appleton \& Co: New York, was also used.

63. Norgaard, R. L. (1981), op. cit., p. 35.

64. Smith, E. L. (1924), Common Stocks as Long-Term Investments, London: Macmillan.

65. Dewing, A. S. (1922), Corporate Finance, New York: The Ronald Press Co. This was an abridged edition of Dewing's earlier mammoth work: Dewing, A. S. (1919), The Financial Policy on Corporations, The Ronald Press Co.: New York.

66. Gerstenberg, C. (1924), Financial Organisation and Management of Business, Prentice-Hall: New York. This was essentially an abridged version of Gerstenberg's earlier magnum opus: Gerstenberg, C. (1915), Materials in Corporation Finance, Prentice-Hall: New York.

67. Chamberlain, L. (1917), The Principles of Bond Investment, $7^{\text {th }}$ ed., New York: H. Holt.

68. Bogan, J. I. (1928), Analysis of Railroad Securities, New York: Ronald Press Co.

69. See Heilman, R. E., Kiekhofer, W. H., Ruggles, C. O., Sharfrman, I. L., and Marshall, L. C. (1928), "Collegiate Education for Business", The Journal of Business of the University of Chicago, 1(1): pp. 1-59; and Ruml, F. (1928), op. cit.

70. Murray, R. F. (1984), "Graham and Dodd: A Durable Discipline”, Financial Analysts Journal, 40(5): pp. 18-19, 22-23 at 19.

71. Murray, R. F. (1984), loc.cit.

72. Hence the popularity of U.S. texts such as Hardy, C. O. and Cox, G. V. (1927), Forecasting Business Conditions, New York: Macmillan. Similarly in Australia as recently as the 1960s, texts such as Matthews, R. C. O. (1959), The Trade Cycle, Digswall Place, England: Nisbet, were utilised.

73. Graham, B. and Dodd, D. L. (1934), Security Analysis: Principles and Technique, New York: McGraw Hill.

74. Murray, R. F. (1984), op. cit., pp. 18-20. 
practice; and to evaluate the best way to proceed in terms of theory, curriculum development, and student learning outcomes.

\section{Disconnects Between Theory, Curricula, and Practice}

The features of the GFC noted earlier ${ }^{91}$ would be recognized in many extant university curricula not as finance, but as the subject of other disciplines. For example, contagion, moral hazard, adverse selection, and uncertainty are often seen to be the province of economics. Issues concerning incomplete and optimal contracting are frequently seen to relate purely to law and legal analysis. Behavioural finance issues such as anchoring and belief perseverance are perceived to be within the realm of applied psychology, while the last factor is usually seen as a matter of ethics or moral philosophy. There is no denying that it is helpful and entirely legitimate to view such issues through different lenses. However, what is surprising - indeed, perhaps disturbing if our graduate learning outcomes include content that is relevant and useful—is the conspicuous absence of these issues from many of existing university finance curricula.

There would appear to be two reasons for this. The first is that we do not yet have a single unified theory that explains and predicts finance practice, but rather a number of sometimes complementary, sometimes competing "piecemeal" theories. Consider, for example, capital structure and dividend policy—we have not one theory, but several. Similarly, many finance academics seeking to explain the GFC to their students may feel somewhat hampered by our current lack of a

75. See e.g. Phelps, O. W. (1946), "The Case for an Active Association of Collegiate Schools of Business", The Journal of Business of the University of Chicago, 19(3): pp. 183-193; Ellis, H. S. (ed.) (1948), A Survey of Contemporary Economics, Philadelphia PA: The Blackiston Company, pp. 106-107; 300-301; Ch. 9; and Ch. 13 (esp. pp. 455-459); Calkins, F. J. (1949), "University Courses in Finance", Journal of Finance, 4(3): pp. 244-265, at 245, 257. This angst continued through the 1960s to the 1980s: see e.g. Robinson, R. I. (1966), "What Should We Teach in a Money and Banking Course?", Journal of Finance: Papers and Proceedings, 21(2): pp. 403-410; Petry, G. H. (1981), "A History and Analysis of Scholarly Papers Presented at the Seven Academic Finance Associations from 1939 through 1980", Financial Management, 10th Anniversary Issue: The Evolution of the Finance Discipline, 10(2): pp. 93104, at 97; and Hastie, K. L. (1982), “A Perspective on Management Education”, Financial Management, 11(4): pp. 55-62.

76. Spens, W. (1945), University Education and Business, Cambridge: Cambridge University Press, p. (v); Urwick L. (1945), Education for Management: Management Subjects in Technical and Commercial Colleges: cited in Murphy, M. E. (1953), op.cit., pp. 41-42; Rose, J. R. (1947), "Business Education in a University", The Journal of Business of the University of Chicago, 20(4): pp. 183-190, at 189; Urwick, L. (1950), "A British Graduate School of Business", British Management Review, pp. 15-23; and Murphy, M. E. (1953), "Education for Management in Great Britain", The Journal of Business of the University of Chicago, 26(1): pp. $37-47$, at 37,43 .

77. See, for instance, Murphy, M. E. (1941), "The English Approach to the Distribution of Securities", The Journal of Business of the University of Chicago, 14(4): pp. 372-383.

78. See, for example, Hunt, P. (1950), "Materials and Methods of Teaching Business Finance (III)", Journal of Finance, pp. 280-284; and Norgaard (1981), op. cit., p. 37. 
unified theory which encompasses and explains the main characteristics of the GFC, including contagion, moral hazard, adverse selection, uncertainty, incomplete and optimal contracting, behavioural finance issues and, perhaps, a lack of ethics.

The second is that most finance textbooks are not addressing these developments in practice - and it is the leading textbooks on which many finance curricula rely for their content and pedagogy. This is despite the fact that leading finance journals are now (and have been for some time) addressing these developments in practice, notwithstanding our lack of a single completely unifying theory to explain the GFC. For example, more than 15 years ago, Brennan noted the importance of incomplete and sub-optimal contracting and legal arrangements. ${ }^{92}$ The concept of socially optimal liquidation, for example, would appear to be directly relevant to corporate collapses during the GFC. At the same time, Brennan referred to a growing theoretical and empirical finance literature on adverse selection, signalling and screening in the markets; moral hazard and agency in the theory of the corporation; corporate bankruptcy under conditions of asymmetric information and free rider problems; and capital allocation decisions. ${ }^{93}$ All of these topics would appear to be directly relevant to issues surrounding the GFC, and yet few have been incorporated into university finance curricula, even in the aftermath of the GFC.

79. See e.g. Bion, B. and Upton, M. H. (1953), Introduction to Business Finance, New York: McGraw-Hill; and Hunt, P., Williams, C., and Donaldson, G. (1958), Basic Business Finance: Text and Cases: Richard D. Irwin: Homewood Ill.; and Bion, B. and Upton, M. H. (1953), Introduction to Business Finance, New York: McGraw-Hill.

80. Calkins, F. J. (1950), "Materials and Methods of Teaching Business Finance (II)", Journal of Finance, p. 275 at 277.

81. Weston, J. F. (1970), "The State of the Finance Field”, Appendix B to Kavesh, R. A., Weston J. F., and Sauvain, H. (1970), “The American Finance Association: 1939-1969”, Journal of Finance, 25(1): pp. 1-17, at 16.

82. Petry, G. H. (1981), op. cit., pp. 99, 103.

83. Petry, G. H. (1981), op. cit., p. 99; and Borokhovich, K. A., Bricker R. J., Zivney, T. L., and Sundaram, S. (1995), "Financial Management (1972-1994): A Retrospective", Financial Management, 24(2): pp. 42-53.

84. Brennan, M. J. (1995), "Corporate Finance over the past 25 Years", Financial Management, 24(2): pp. 9-22, at 9-10. Examples include the Modigliani-Miller propositions about dividend theory and capital structure policy under ceteris paribus assumptions.

85. Ibid.

86. See for example, the changes through older editions of Copeland and Weston, op. cit.; and of introductory and intermediate texts such as Pierson, Bird, Brown, and Howard, op. cit.; and Bishop, S. R., Faff, R., Oliver, B. R., and Twite, G. J. (2004), $5^{\text {th }}$ ed., Corporate Finance, Sydney: Prentice-Hall (cf. Bishop, S. R., Crapp, H. R., and Twite, G. J., Corporate Finance, Holt Rinehart and Winston in older editions).

87. Brennan, M. J. (1995), op. cit., p. 11. Cf. Andrews, T. L. (1979), "Sterile Premises in Corporate Capital Theory", Financial Management, 8(4): pp. 7-11, which continues a line of such criticism at least since Sauvain, H. (1970), "The State of the Finance Field: Comment", Journal of Finance, 25(1): p. 17. 


\section{Where to from Here? Quo hinc?}

So...quo hinc? In terms of workable revisions to enhance the relevance of finance curricula in the wake of the GFC, a number of key changes readily come to mind -albeit changes which would require, to some extent, the use of a multidisciplinary approach which applies complementary aspects of finance, economics, psychology, law and accounting scholarship.

\subsection{Highlighting the Importance of Uncertainty}

First, there could be a greater emphasis on techniques for ex ante recognising uncertainty, as distinct from risk, without significant disruption to the curriculum. Extant finance curricula generally do a good job of helping students to learn the most popular methods of analysing uncertainty, such as rank dependence ${ }^{94}$ (e.g. best-to-worst case scenarios), prospect theory, ${ }^{95}$ Bayesian models,,${ }^{96}$ and multiple priors. $^{97}$

However, university finance curricula are generally not so good at helping students to identify and map sources of substantial uncertainty, as distinct from risk; and conventional risk/return models such as the capital asset pricing model do not-at least as traditionally taught - capture ex ante uncertainty, which remains the elephant in the room. Whereas risk can be quantified using exogenous, objectively known probabilities (useful for risk-return models), such probabilities are inherently almost impossible to determine for unique events ${ }^{98}$

88. Adams, J. D. et al. (2001), Collapse Incorporated: Tales, Safeguards and Responsibilities of Corporate Australia, Sydney: CCH.

89. Cf. Dubin, R. (1978), Theory Building, $2^{\text {nd }}$ ed., New York: Free Press.

90. Cf. Zingales, L. (2000), "In Search of New Foundations", Journal of Finance, 55: pp. 16231653.

91. Section 2 of the paper.

92. Brennan, M. J. (1995), op cit., p. 15 and the references cited therein.

93. See Brennan, M. J. (1995), op. cit., and the articles listed therein.

94. See Quiggin, J. (1982), "A Theory of Anticipated Utility”, Journal of Economic Behaviour and Organisation, 3: pp. 323-343; and Schmeidler, D. (1989), "Subjective Probability and Expected Utility Without Additivity", Econometrica, 57: pp. 571-587.

95. See Tversky, A. and Kahneman, D. (1992), "Advances in Prospect Theory: Cumulative Representation of Uncertainty", Journal of Risk and Uncertainty, 5: pp. 297-323.

96. See for instance, Ramsey, F. (1931), op. cit; Savage, L. (1954), The Foundations of Statistics, New York: Wiley; Machina, M. and Schmeidler, D. (1992), "A More Robust Definition of Subjective Probability", Econometrica, 60: pp. 745-780; and Greenspan, A. (2004), "Innovations and Issues in Monetary Policy: The Last 15 Years", American Economic Review: Papers and Proceedings, 94: pp. 33-40.

97. See Wald, A. (1950), Statistical Decision Functions, New York: Wiley; Budescu, D. and Wallsten, T. (1987), "Subjective Estimation of Precise and Vague Uncertainties", in Wright, G. and Ayton, P. (eds.), Judgmental Forecasting, New York: Wiley; Kyburg, H. (1983), Epistemology and Inference, Minneapolis: University of Minnesota Press; and Manski, C. (2004), "Measuring Expectations", Econometrica, 72: pp. 1329-1376. 
such as a GFC, or the fallout for individual firms arising from it. Uncertainty, with unknown probabilities, can be assessed only subjectively. As part of a reformed curriculum, the events culminating in the GFC, together with its attendant uncertainties, provide a matchless set of case studies, directly on point, which students could use in the classroom to identify and map the main sources and impacts of uncertainty.

\subsection{Reducing Complexity and Information Asymmetry by Broadening} Knowledge Through a Cross-Disciplinary Approach

A second and related shortcoming is that, because of information asymmetry and agency costs which are spread across an interconnected network of contracts both inside and outside the firm, financial intermediaries can extract rents for, and transfer wealth to, themselves by increasing the complexity of new securities and products they issue. ${ }^{99}$ A high level of complexity in financial products and transactions in the face of investor and market ignorance amplifies the effects of uncertainty.

Much of this product innovation was presumably a consequence of financiers seeking to circumvent legal and regulatory proscriptions, with the result that greater complexity and extensive mandated disclosure, rather than clarifying, apparently obfuscated the understanding even of many "sophisticated investors". 100 Concepts such as "deferred equity", "equity bridges", "rolling instalment warrants", credit default swaps, collateralised debt obligations, and "performance dividends" are not found in most texts or curricula, despite their prevalence in practice. People have limited capacity to absorb information unless they are given a sufficiently long time to process it: they exhibit "bounded" rationality. ${ }^{101}$ Greater disclosure cannot guarantee understanding; understanding requires education and learning. ${ }^{102}$

In the context of securitisation particularly, providers of complex financial products make their money by exploiting the information asymmetry and agency costs that are spread across the network of contracts both inside and outside the firm, ${ }^{103}$ in the form of economic rents and wealth transfers. There is little

98. Wakker, P. P. "Uncertainty", in Durlauf, S. N. and Blume, L. E. (eds), The New Palgrave Dictionary of Economics, $2^{\text {nd }}$ ed., Palgrave Macmillan, 2008; Knight, F. (1921), op. cit.; and Ramsey, F. (1931), "Truth and Probability", in The Foundations of Mathematics and Other Logical Essays, London: Routledge and Kegan Paul.

99. See Parliamentary Joint Committee on Corporations and Financial Services (Nov. 2009), Inquiry into Financial Products and Services in Australia, Australian Government, Canberra.

100. This is a legal term defined by the corporations and securities legislation - see for example, Chapter 6D (and particularly s. 708) of the Australian Corporations Act (Cth).

101. Cyert, R. M. and March J. G. (1963), A Behavioral Theory of the Firm, Englewood Cliffs, NJ: Prentice Hall; and Simon, H. A. (1957), Models of Man, New York: Wiley.

102. Greater transparency is not therefore a panacea for these types of ills, as much financial law (which appears to be based largely in financial theory) seems to assume. 
pedagogical reason why the financial economic theory underlying wealth transfers should not be taught to students from a prudential investment perspective - they are, after all, tomorrow's investors or investment advisors. ${ }^{104}$ Moreover, in the wake of the GFC, finance students should be exposed to the cross-disciplinary complexity of contemporary financial products - not only so that in later practice when to engage a lawyer, specialist tax accountant or specialist merchant banker for advice, but also so that they can explain to such advisors the underlying mechanics of complex financial instruments and transactions, to enable the provision of meaningful and accurate legal or taxation advice. ${ }^{105}$

Financial product complexity will not diminish - if anything, investment products will continue to become even more complex and sophisticated. Yet we do insufficient service to our students if all we can tell them is that ongoing innovation in securitisation will ensure that financial products may well be very different shortly after they graduate. The answer, then, lies with enhancing reducing uncertainty and ignorance through education and true learning, with a multi-disciplinary approach involving finance, law, accounting and economics. More than 15 years ago, Brennan highlighted the importance of attention to institutional detail. ${ }^{106}$ In educational terms, if we do nothing else, we must surely produce graduates with the wherewithal:

- after a careful reading of relevant disclosure documents associated with such products (e.g. information memoranda, which can readily be

103. The success of virtually all sophisticated financial investment products and transactions in practice depends on interconnected chains (networks) of financiers, equitable security assignees, trustees and beneficiaries, insurers and sub-insurers. Like many networks, these contractual networks can be subject to spillovers and contagion, the effects of which are magnified because of the interdependencies within the network. Investors in sophisticated securities, for example, cannot - because of privity of contract - demand to see the books of the "sub-sub-sub-insurer" who will ultimately indemnify the issuer's obligations to pay the interest due to them; or the remuneration contracts of those insurance executives who advise their Boards to sign off on the "sub-sub-sub-insurance" contract - yet the viability of the securities as an investment is often thoroughly dependent on them.

104. Academic reticence to do so may perhaps be explained by ethical concerns; or information asymmetry on the part of the lecturer. The latter is readily rectified. And as for academic concerns about the ethics of teaching students about wealth transfers, it may be that publicity is the best prophylactic to unethical behaviour.

105. Lawyers or tax accountants are specialists in law or tax accounting, but not necessarily in finance. There is a view, widely held in practice, that one of the main reasons for engaging legal or accounting advisors is to transfer risk from the financier to their lawyers or tax accountants. Sadly, such views are generally mistaken - lawyers (and accountants, though admittedly less so based on some high profile legal cases involving them) are past masters at transferring the risk right back again.

106. Brennan, M. J. (1995), op. cit., p. 13. See also Benveniste, L. M. and Wilhelm, W. J. (1990), "A Comparative Analysis of IPO Proceeds under Alternative Regulatory Environments", Journal of Financial Economics, pp. 173-208; and Chowdhry, B. and Sherman, A. (1994), "International Differences in Oversubscription and Underpricing of IPOs", UCLA Working Paper No. 12-94, University of California, Los Angeles, cited in Brennan, M. J. (1995). 
accessed online under the continuous disclosure regime under the relevant corporations and securities legislation), to analyse or break down sophisticated financial products into their fundamental conceptual building blocks, so that they can

- appreciate the risk/uncertainty/return relationship and communicate this to clients and other stakeholders;

- apply their knowledge to new situations;

- synthesize or put together these fundamental building blocks in a novel way to develop new products and investment perspectives consistent with corporate finance law;

- to appreciate that financial investment, financing and dividend decisions are constrained by the law, including

- fiduciary and statutory duties such as conflicts of interest, duty of care and skill, profit from position and information; insider trading and market manipulation regulation;

- mandatory fundraising disclosure regulation (it is, after all, the law that keeps financial markets informationally efficient);

- the moral hazard of limited liability conferred by corporations legislation, and the checks and balances which become necessary as a consequence, including the outcomes of regulatory gaming in relation to trusts and other forms of asset protection for management and directors;

- to identify and understand so-called Ponzi schemes and the wealth transfers they involve between stakeholder groups in financial practice; and

- to understand and think critically about the role of professional ethical responsibilities in finance and financial planning - e.g. is it morally ethical to engineer the transfer of wealth from one class of security holders to another, or from one class of security holders to management; or for management and directors to use other people's (banks', large vs. small investors') money to take on high risk projects, when management and directors have asset protection - including the use of family discretionary trusts and phoenix companies-that effectively give them a call option in terms of their personal wealth (i.e. 
limited downside and unlimited upside potential)? ${ }^{107}$ Arguably, ethics should be embedded in an integrated, applied way in the curriculum, rather than as a "six week, stand alone" component of the course. Subjects on ethical investing (or, as North Americans term it, socially responsible investing) could also fruitfully be introduced as they have in some universities such as Griffith in Australia.

Should such reforms of finance curricula be left to the postgraduate years? Assuming that usefulness of finance curricula and enhancing all graduates' understandings of praxis are relevant criteria, the better answer would appear to be that these aspects of "real world" finance should be learned in the undergraduate years - perhaps a final year "capstone" course - rather than left until postgraduate study. This is for two reasons. Firstly, most students do not undertake in depth postgraduate study, while all are-by definition-at least exposed to undergraduate programs. ${ }^{108}$ Secondly, if the tenor of the Federal Government's Inquiry into Financial Products and Services (Nov. 2009) ${ }^{109}$ is accepted, finance graduates need to be more financially literate in these practical aspects now. Pedagogically speaking, the more students are exposed to these concepts, and the quicker, the better.

Finally, if we are learn the lessons of the GFC, it is important that finance students become skilled at recognising and understanding the impacts of different contractual design arrangements, adverse selection, uncertainty, networks, contagion, moral hazard, the cognitive impacts of increased complexity, ethics, and how these apply in financial markets.

\section{Summary and Conclusions}

Finance curricula in Universities have been criticized in the financial press in the wake of the GFC. How did we get to this point? In large part (though not exclusively), it is because we currently lack a unified theory that encompasses:

107. John Kenneth Galbraith argued that the " $21^{\text {st }}$ century has a corporate system based on the unrestrained power of self-enrichment"; and described the contemporary corporate world as analogous to a harlot who dresses very nicely: Galbraith, J. K. (2004), The Economics of Innocent Fraud: Truth for Our Time, New York: Houghton Mifflin Co., pp. 44 and 15-21 respectively. Quaint as it sounds, there is probably a need to address the current lack of a "moral compass" that moral relativism and antinomianism have wrought in the investment community. What is the best way to combat this? Rather than moralise - at the risk of sounding sanctimonious - about the evils of greed, why not teach students about the causes and effects of wealth transfers within and between companies and corporate stakeholders? Publicity may be the best prophylactic to unethical conduct.

108. Or to courses that are "postgraduate" in time but undergraduate in depth.

109. Parliamentary Joint Committee on Corporations and Financial Services (Nov. 2009), op. cit. 
i. Contagion, moral hazard, adverse selection, uncertainty (often perceived as economics, rather than finance);

ii. Incomplete and sub-optimal contracting (frequently considered matters of law or legal theory, as distinct from finance);

iii.Behavioural finance, including anchoring and belief perseverance (often perceived as the realm of psychology, rather than finance); and arguably

\section{iv. A lack of ethics (generally considered as moral philosophy).}

Many commentators would argue that these factors coalesced in the GFC. Pedagogically, the usefulness of finance curricula - and students' learning outcomes - could be considerably enhanced by highlighting the role played by uncertainty as well as risk in financial analysis case studies (e.g. from the GFC), and emphasizing the cross-disciplinary nature of finance in practice. Students could be given the opportunity in a final year, "capstone" course ${ }^{110}$ to:

110. For scholars interested in capstone courses from an educational design perspective, see the development of ideas in Uddin, M. and Swope, R. D. (1994), "Fostering Industrial Partnerships in Undergraduate Capstone at Trinity", Proceedings, 1994 Advances in Capstone Education Conference, Brigham Young University, pp. 17-24; Todd, R. H., Magleby, S. P., Sorensen, C. D., Swan, B. R., and Anthony, D. K. (1995), "A Survey of Capstone Engineering Courses in North America", Journal of Engineering Education, April, pp. 165-174; Dutson, A. J., Todd, R. H., Magleby, S. P., and Sorensen, C. D. (1997), "A Review of Literature on Teaching Engineering Design Through Project-Oriented Capstone”, Journal of Engineering Education, January, pp. 17-28; Etheridge, H. L. (2001), "E-Business Education at AACSB-Affiliated Business Schools: A Survey of Programs and Curricula", Journal of Education for Business, 76(6): pp. 328-331; Stephen, J., Parente, D., and Brown, R. C. (2002), "Seeing the Forest and the Trees: Balancing Functional and Integrative Knowledge Using Large-Scale Simulations in Capstone Business Strategy Classes", Journal of Management Education, 26: pp. 64-193; Davis, C. H. (2004), "Enterprise Integration in Business Education: Design and Outcomes of a Capstone ERP-Based Undergraduate E-Business Management Course", Journal of Information Systems Education, 15(3): pp. 287-299; Brooks, R., Benton-Kupper, J., and Slayton, D. (2004), "Curricular Aims: Assessment of a University Capstone Course", The Journal of General Education, 53 (3-4): pp. 275-287; Jervis, K. J. and Hartley, C. A. (2005), op. cit.; Todd, R. H. and Magleby, S. P. (2005), "Elements of a Successful Capstone Course Considering the Needs of Stakeholders", European Journal of Engineering Education, 30(2): pp. 203-214; Szwed, P. S. (2005), "Broadly Assessing Management Discipline Competence Using a Capstone Public Management Consulting Course", in Martell, K. and Calderon, T. (eds.) "Assessment in the Disciplines", Assessment of Student Learning in Business Schools: Best Practices Each Step of the Way, 1(1), Tallahassee, FL: Association for Institutional Research, Florida State University; Goldberg, J. (2007), "Capstone Design Courses" in Enderle, J. D. (ed.), Synthesis Lectures on Biomedical Engineering, Connecticut: Morgan and Claypool; Moore, R. (2008), "Capstone Courses", available at http://users.etown.edu/m/ moorerc/capstone.html (accessed 15.12.11); Gilinsky, A. and Robison, R. (2008), “A Proposed Design for the Business Capstone Course with Emphasis on Improving Students' Information Competency", Journal of Management Education, 32(4): pp. 400-419; and Kachra, A. and Schnietz, K. (2008), "The Capstone Strategy Course: What Might Real Integration Look Like?", Journal of Management Education, 32, pp. 476-508. 
i. Map the cash flows and wealth transfers between stakeholders in real life sophisticated financial products and transactions, based on publicly available disclosure documents, and if appropriate, re-arrange the cash flows to derive new financial products consistent with corporate finance law; as well as

ii. Recognize:

- the moral hazard effects of limited liability conferred by corporations legislation and trust law, and all the checks and balances which become necessary as a consequence;

- Ponzi and other wealth transfer schemes in practice;

- the ethical implications of wealth transfers between stakeholders;

- contagion; and

- incentives for adverse selection and moral hazard.

By doing so, not only would students' learning outcomes be enhanced, but we could be better assured that future students could ultimately help us to articulate a unified finance theory that can better accommodate these salient features of finance in practice. 
